\title{
An unusual cause of hypercalcemic crisis: Water-clear cell double parathyroid adenoma
}

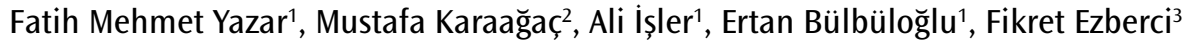

\begin{tabular}{|c|c|}
\hline \multirow[t]{5}{*}{ ABSTRACT } & $\begin{array}{l}\text { Objective: To evaluate the clinical characteristics of a patient operated for water-clear cell adenoma and to discuss } \\
\text { these in the light of relevant literature. }\end{array}$ \\
\hline & $\begin{array}{l}\text { Material and Methods: PubMed and Google Scholar were searched to identify articles related to water-clear cell } \\
\text { adenoma using the following keywords: parathyroid tissue, parathyroid gland, parathyroid cells, parathyroid ad- } \\
\text { enoma, parathyroid hyperplasia, water-clear-cell, and water clear cell. The search included case reports, review } \\
\text { articles, and original articles that had been published between January } 1990 \text { and November } 2014 \text { without any } \\
\text { restrictions on language. All articles that contained information on the study population and treatment related data } \\
\text { were identified and retrieved. In addition, an evaluation was of a case of a } 47 \text {-year-old male patient with PHC who } \\
\text { was treated at our clinic was conducted. }\end{array}$ \\
\hline & $\begin{array}{l}\text { Results: A total of } 19 \text { patients, including our new case, (age range: } 18 \text { to } 81 \text { years, mean } \pm \text { SD: } 57.47 \pm 16.31 \text { years) } \\
\text { were included in the analysis. Eleven patients were female. Information about adenoma location was available from } \\
\text { studies involving } 17 \text { patients and they indicated the following distribution of locations: left inferior ( } n=10) \text {, right su- } \\
\text { perior }(n=4) \text {. When preoperative imaging methods were examined, a false negative result was given by ultrasonog- } \\
\text { raphy in } 28.5 \% \text { of patients and only } 57.1 \% \text { were positive on scintigraphy. Concomitant thyroid papillary carcinoma } \\
\text { was determined in } 1 \text { patient. The mean tissue dimensions were } 3.47 \pm 1.73 \mathrm{~cm} \text { (range, } 0.8-6.8 \mathrm{~cm} \text { ). }\end{array}$ \\
\hline & $\begin{array}{l}\text { Conclusion: Water-clear cell adenoma, which shows similar clinical characteristics to other parathyroid adenomas, } \\
\text { is an uncommon cause of hyperparathyroidism. }\end{array}$ \\
\hline & Keywords: Double water-clear cell adenoma, hyperparathyroidism, hypercalcemic crisis \\
\hline
\end{tabular}

Cite this paper as: Yazar FM, Karaağaç M, İşler A, Bülbüloğlu E, Ezberci F. An unusual cause of hypercalcemic crisis: Waterclear cell double parathyroid adenoma. Turk J Surg 2017; 33: 243-247.

'Department of General Surgery, Sütçü Imam University School of Medicine, Kahramanmaraş, Turkey 2Department of Pathology, Sütçü Imam University School of Medicine, Kahramanmaraş, Turkey ${ }^{3}$ Department of General Surgery, Ümraniye Training and Research Hospital, İstanbul, Turkey

Address for Correspondence Fatih Mehmet Yazar e-mail: fmyazar@ksu.edu.tr

Received: 04.04.2016 Accepted: 26.07.2016

@Copyright 2017 by Turkish Surgical Association

Available online at www.turkjsurg.com

\section{INTRODUCTION}

Primary hyperparathyroidism is one of the most encountered endocrine pathologies, with an incidence of $21.6 / 100,000$. In the etiology, the leading cause is solitary adenoma (87\%-91\%), generally originating from chief cells (1). Adenoma originating from more than one gland is a rarer event and comprises $2 \%-15 \%$ of all adenomas (2). The rare form (1\%) of water-clear cell hyperplasia (WCCH) of hyperparathyroidism was first described by Albright et al. (3) in 1934. As adenoma in the etiology is even more uncommon, only 19 cases have been reported since 1994, and of those cases, adenoma was in both parathyroid glands in only one case $(1,2,4-20)$.

Hypercalcemic crisis, which was first described by Hannas in 1939, is a severe and life-threatening condition of severe hypercalcemia progressing to associated failure of various systems (21). Of the known cases, the case reported here is the first of hypercalcemic crisis caused by water-cell clear adenoma (WCCA). In previous reports related to WCCA, the histopathological features of the disease have generally been the focus. The aim of this study was to present the preoperative and postoperative periods of the disease and to evaluate the clinical characteristics. Defining the clinical characteristics of these kinds of rare cases can be considered useful for clinicians.

In this case report, we present a patient who was successfully treated for double WCCA, and the case is discussed in comparison with the 19 cases reported in literature.

\section{MATERIAL AND METHODS}

A new case of WCCA with hyperparathyroidism is presented in this study and it was aimed to evaluate the preoperative clinical features and postoperative follow-up period in a comparison with other reports in literature of patients operated on for WCCA. Therefore, between January 2016 and March 2016, two of the authors scanned the PubMed and Google Scholar databases for publications between January 1, 1990 and March 212016 using the key words (Parathyroid tissue* OR Parathyroid gland* OR Parathyroid cells*) AND (Parathyroid adenoma* OR Adenoma*) AND (Water-clear-cell* OR water clear cell*) (Field: All Fields) (Figure 1). A total of 17 publications were determined, containing 19 patients with the demographic and technical data such as year of publication, patient age, gender, radiological and operative findings, and 
Databases: PubMed/Google Scholar keywords:

(Parathyroid tissue or Parathyroid gland or Parathyroid cells) and (Parathyroid adenoma or Parathyroid hyperplasia) and (Water-clear-cell or water clear cell)

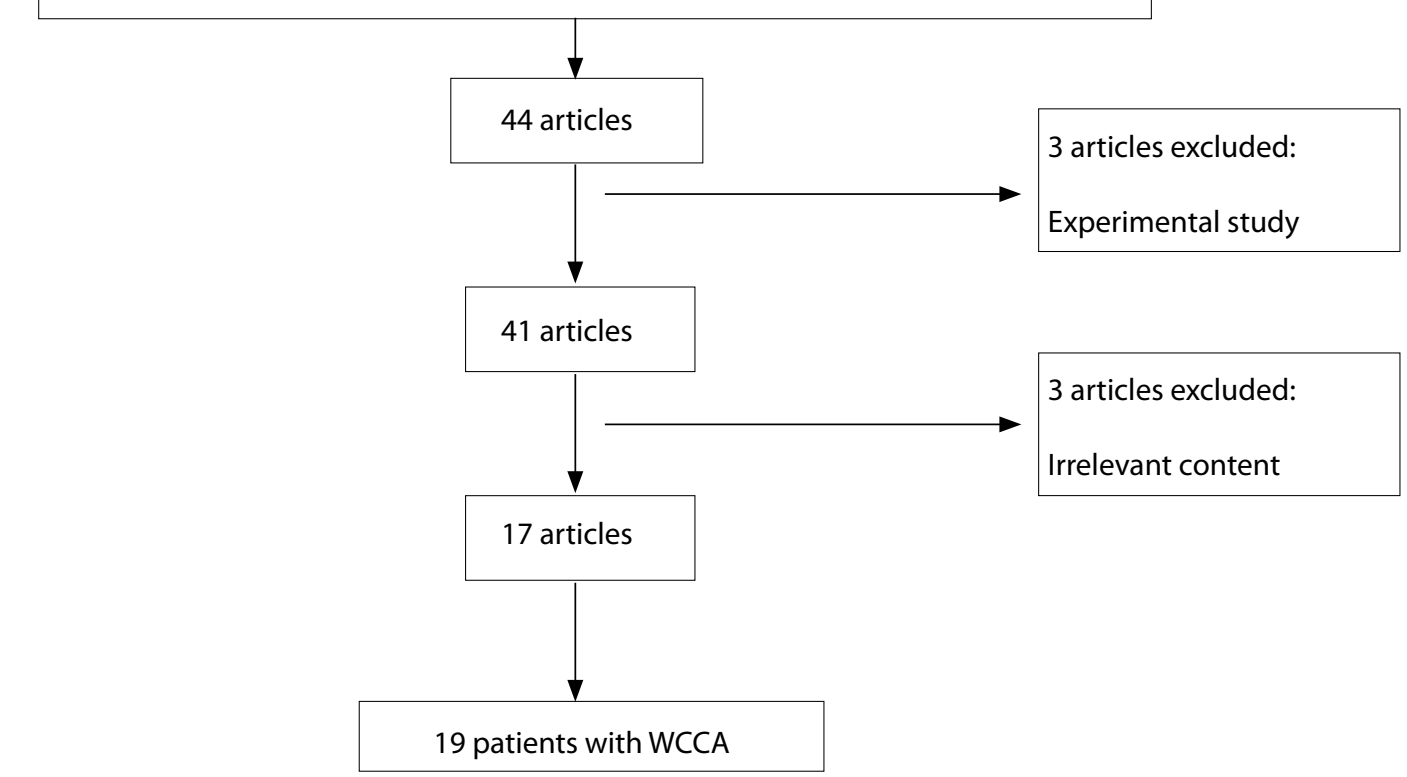

Figure 1. Flow chart of the patient selection and exclusion criteria

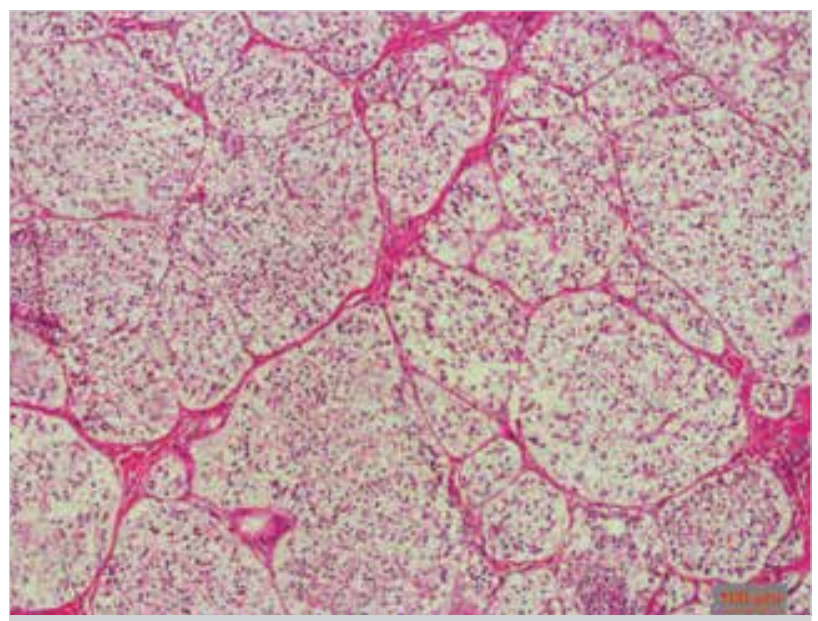

Figure 2. Histological appearance of the water-clear cell parathyroid adenoma. The cells show minimal nuclear pleomorphism and have uniformly foamy cytoplasm (hematoxylin and eosin, original magnification: 100x.)

preoperative diagnostic methods. All procedures performed in studies involving human participants were in accordance with the ethical standards of the institutional and/or national research committee and with the 1964 Helsinki declaration and its later amendments or comparable ethical standards.

\section{RESULTS}

\section{Case Report}

A 47-year-old male patient was referred to our clinic when hyperparathyroid was determined during investigations for crine neoplasia or familial hyperparathyroidism, and no concomitant disease was determined except for kidney stone. Clinically, the patient had complaints of abdominal pain, nausea, vomiting, and lethargy. In the biochemical analyses, test results were determined as serum calcium of $16.6 \mathrm{mg} / \mathrm{dL}$ (reference range $8.5-10.1 \mathrm{mg} / \mathrm{dL}$ ) and an intact parathyroid hormone level (iPTH) of $744 \mathrm{pg} / \mathrm{mL}$ (reference range 11-67 $\mathrm{pg} / \mathrm{mL}$ ). Therefore, to bring the hypercalcemia under control, treatments were applied of hydration, subcutaneous calcitonin, and parenteral biphosphonate (Zoledronic acid: Zometa ${ }^{\oplus}$ ampoule Novartis, Stein, Switzerland). When the Ca level receded to 10.7, ultrasonography (USG) was performed and a well-defined, separated lesion was determined in the inferior pole of both thyroid glands; on the right side in the inferior posterior lobe, $2.2 \times 1.1 \times 0.7 \mathrm{~cm}$ in size, and on the left side, $1.6 \times 1.0 \times 0.7 \mathrm{~cm}$ in size. However, the lesions determined on USG could not be observed on Technetium-99m-sestamibi (MIBI) examination.

The patient was admitted for surgery with an initial diagnosis of double parathyroid adenoma. During the operation, lesions were excised from the inferior pole of both thyroid lobes, which were clearly separated between the thyroid gland and the intermediary planes, $2.5 \times 1.1 \times 0.7 \mathrm{~cm}$ in size on the right side and $1.6 \times 1.0 \times 0.7 \mathrm{~cm}$ on the left. These lesions were consistent with bilateral parathyroid adenoma. As the lesions were determined as adenoma in the intraoperative "frozen" section examination, the upper parathyroid glands were explored and biopsy and frozen section examination were applied. With the report of normal parathyroid tissue, the procedure was completed.

In the postoperative histopathological examination, both lesions were seen to be consistent with WCCA (Figure 2). In the 
$48^{\text {th }}$ month postoperatively, the PTH level had recovered to $43.6 \mathrm{pg} / \mathrm{m} \mathrm{L}$ and Ca to $9 \mathrm{mg} / \mathrm{dL}$.

\section{Literature Review}

Using PubMed and Google Scholar, English-language medical literature published between January 1990 and March 2016 was searched. A total of 17 reports concerning 19 cases of WCCA with hyperparathyroidism meeting the aforementioned criteria were included in this review. The patients were aged from 18 to 81 years (mean, $57.47 \pm 16.31$ years); 11 were female (57.9\%) and 8 were male (42.1\%).

Double adenoma was seen in only 1 patient. Except for 2 articles, all other publications included a single patient. In 1 patient, there was concomitant multiple endocrine neoplasia type 1 (MEN-1); in 1 patient, neurofibromatosis type 1 (NF-1); and in all others, it was found to be sporadic. The most common adenoma localization was the left inferior parathyroid gland $(n=10)$, followed by the right lobe upper pole $(n=4)(4$, 12). In 1 patient, the lesion was reported to be located in the left thyroid lobe (8). Prior to the current patient, more than one adenoma was seen in only 1 patient, and these were located in the upper pole (9). In the 14 patients with available preoperative imaging data, USG and scintigraphy showed lesions in 6 patients, and in 1 patient, where both imaging methods had a negative result, the diagnosis was seen to have been made clinically. In 4 patients with negative scintigraphy results, diagnosis was made from USG, and 2 patients were diagnosed from scintigraphy. Apart from parathyroidectomy, total or subtotal thyroidectomy was performed in 3 patients $(8,9,14)$. In 1 patient, thyroid papillary carcinoma was seen concomitant to the adenoma (14). The mean tissue size was $0.47 \pm 1.73 \mathrm{~kg} /$ $\mathrm{m}^{2}$, (range, 0.8-6.8). No postoperative recurrence was seen in any patient, including the patient who underwent surgery for double adenoma. The clinicopathological characteristics of the 19 patients are summarized in Table 1.

\section{DISCUSSION}

Primary hyperparathyroidism is one of the most frequently encountered clinical events within endocrine diseases. The disease generally originates from chief or oxyphilic cells, and has been rarely (1\%) determined to originate from the hyperplasia seen in water-clear cells. Following the first case of WCCA reported in 1994, to the best of our knowledge, there have only been 19 cases in literature (1, 2, 4-20).

Multiple parathyroid adenomas constitute $2 \%-15 \%$ of all adenomas (9). According to the criteria defined by Harness et al. (22) to be able to make a diagnosis of multiple parathyroid adenoma, I) in the operation, there must be more than 1 and fewer than 4 involvements of the parathyroid gland, II) at least 1 of the parathyroid glands must be normal, III) there must not be multiple endocrine neoplasia or familial hyperparathyroidism, and IV) postoperatively permanent normocalcemia must be able to be obtained in the patient. In the current case, as a lesion consistent with adenoma was determined on preoperative USG with localization in both inferior parathyroid glands, surgery was planned preoperatively for the exploration of the four parathyroid glands.

In a report by Kuhel et al. (9), despite an appearance consistent with adenoma only in the right upper pole localization on preoperative imaging, bilateral parathyroid exploration was conducted as potential persistent hyperparathyroidism was considered and adenoma were determined in both superior poles. All the other patients in the literature were operated on for single parathyroid gland involvement, and postoperative hypercalcemia was not observed in any case. When the current case was included, the rate of $1 \%$ bilateral WCCA was decreased. However, as the number of patients is extremely low, it would not be correct to comment on this subject.

Although the origin of water-clear cells is not fully known, it has been suggested that with ageing of the Golgi vesicles or of the granular endoplasmic reticulum cisterns, there is a change in water-clear cells $(6,14,23,24)$. When the age at which the disease was observed was examined, only one patient was 18 years old and the mean age of the patients was 57.47 years (12). As six of the patients were aged over 70 years, it was considered consistent with a relationship between the disease and increased age $(7,14,16,17,19)$. When the current case was evaluated, although the rate of female patients of $55 \%$ $(n=11)$ was slightly low compared to literature, the addition of new patients will clarify this in the future. According to the hypothesis of Kanda et al. (10), although WCCAs reach large sizes, this does not cause severe increases in calcium levels. In the current case, the preoperative serum calcium was $16.6 \mathrm{mg} / \mathrm{dL}$ and a need for preoperative hydration and medical treatment was felt. Hypercalcemic crisis, which is seen in $<1 \%-2 \%$ of primary hyperparathyroid patients, may cause severe and lifethreatening problems in the central nervous system, cardiac, gastrointestinal, and renal functions. Generally, serum calcium levels are $>3.5 \mathrm{mmol} / \mathrm{L}(25,26)$ or $14 \mathrm{mg} / \mathrm{dL}(27)$. Despite there being no clear data in literature correlating to the increased tissue weight or volume of the removed gland of multiple parathyroid adenomas with severe hypercalcemia, it has been emphasized that factors such as accompanying dehydration, reduced calcium excretion, and immobilization could increase the risk of hypercalcemic crisis (28).

There are no previous reports in literature of any patient with WCCA being treated for hypercalcemia and no patient was seen to have calcium levels as high as those observed in the current patient. The total weight of the tissue of the removed parathyroids in the current patient was $2.8 \mathrm{~g}$. Kuhel et al. (9) reported that the total removed tissue weight in the patient operated for double adenoma was $2.2 \mathrm{~g}$ and the preoperative calcium level was $3.3 \mathrm{mmol} / \mathrm{L}$, which was an increase of approximately $25 \%$ over normal. Lower calcium levels in patients with a greater weight of tissue and the relatively high calcium levels in the 2 cases with double adenoma with low tissue weight suggest that there could be a relationship between the number of adenoma and calcium level.

In studies related to the efficacy of USG and scintigraphy in showing adenoma localization, it has been reported that Technetium $99 \mathrm{~m}$ sestamibi scintigraphy (MIBI) has low levels of success in the determination of lesions with a low PTH level and the diagnostic value of USG is higher in this type of lesions (29). When the preoperative imaging methods were examined, it was seen that of the $28.5 \%$ of patients where USG gave false negative results, only $57.1 \%$ were positive on scintigraphy. Khorasani et al. (29) reported that in atypical lesions such as cystic adenoma, USG provided better results for adenoma 
Yazar et al.

An unusual cause of hypercalcemic crisis

Table 1. A brief review of the studies of water-clear cell adenoma

\begin{tabular}{|c|c|c|c|c|c|c|c|c|c|c|}
\hline Study & Years & $\begin{array}{l}\text { Age/gender } \\
\text { (years)/ (F/M) }\end{array}$ & $\begin{array}{l}\text { Concomitant } \\
\text { clinico- } \\
\text { pathological } \\
\text { situation }\end{array}$ & $\begin{array}{l}\text { Preoperative } \\
\text { calcium }\end{array}$ & $\begin{array}{c}\text { Preoperative } \\
\text { PTH }\end{array}$ & $\begin{array}{c}\text { Preoperative } \\
\text { imaging } \\
\text { method }\end{array}$ & $\begin{array}{l}\text { TISSUE } \\
\text { size }\end{array}$ & $\begin{array}{l}\text { Treatment } \\
\text { method }\end{array}$ & $\begin{array}{l}\text { Number of } \\
\text { adenoma }\end{array}$ & $\begin{array}{l}\text { Adenoma } \\
\text { localisation }\end{array}$ \\
\hline Kovasc et al. (4) & 1994 & $48 / M$ & MEN-1 & $11.8 \mathrm{mg} / \mathrm{dL}$ & $435 \mathrm{mlU} / \mathrm{mL}$ & NA & NA & $\begin{array}{c}\text { Total } \\
\text { parathyroidectomy }\end{array}$ & Single & LI \\
\hline Roth et al. (5) & 1995 & $48 / \mathrm{M}$ & & $11.8 \mathrm{mg} / \mathrm{dL}$ & $4.5 \mathrm{mlU} / \mathrm{mL}$ & NA & NA & $P$ & Single & NA \\
\hline Grenko et al. (6) & 1995 & $40 / M$ & & $11.3 \mathrm{mg} / \mathrm{dL}$ & $945 \mathrm{pg} / \mathrm{mL}$ & $\begin{array}{l}\text { USG (-)/ } \\
\text { MIBI (-) }\end{array}$ & $\begin{array}{l}5.0 \mathrm{~cm} \\
(7.6 \mathrm{~g})\end{array}$ & $P$ & Single & RS \\
\hline Begueret et al. (7) & 1999 & $73 / M$ & & $13.8 \mathrm{mg} / \mathrm{dL}$ & $207 \mathrm{pg} / \mathrm{mL}$ & & $2.8 \mathrm{~cm}$ & $P$ & Single & Li \\
\hline Dundar et al. (8) & 2001 & $43 / F$ & & $13.3 \mathrm{mg} / \mathrm{dL}$ & $1667 \mathrm{pg} / \mathrm{mL}$ & $\begin{array}{l}\text { USG (+)/ } \\
\text { Scinti (-) }\end{array}$ & $6 \mathrm{~cm}$ & $\begin{array}{c}\text { Near total } \\
\text { thyroidectomy }\end{array}$ & Single & $\begin{array}{l}\text { Intrathyroidal } \\
\text { Llobe }\end{array}$ \\
\hline Kuhel et al. (9) & 2001 & $56 / F$ & & $3.3 \mathrm{mmol} / \mathrm{L}$ & $52 \mathrm{ng} / \mathrm{L}$ & $\begin{array}{l}\text { USG (+)/ } \\
\operatorname{MIBI}(-)\end{array}$ & $\begin{array}{c}2.8 \mathrm{~cm} \\
(1.7 \mathrm{~g}) \\
1.5 \mathrm{~cm} \\
(0.5)\end{array}$ & $\begin{array}{c}\mathrm{P}+\text { right } \\
\text { lobectomy } \\
\text { and } \\
\text { isthmectomy }\end{array}$ & Double & RS/LS \\
\hline Kanda et al. (10) & 2004 & $52 / \mathrm{F}$ & & $11.7 \mathrm{mg} / \mathrm{dL}$ & $672 \mathrm{pg} / \mathrm{mL}$ & $\begin{array}{l}\text { USG(+)/ } \\
\operatorname{TITC}(+) \\
\operatorname{MR}(+)\end{array}$ & $\begin{array}{l}6.8 \mathrm{~cm} \\
(15.4 \mathrm{~g})\end{array}$ & $P$ & Single & LI \\
\hline $\begin{array}{l}\text { Prasad et al. } \\
\text { (11) }\end{array}$ & 2004 & $40 / F$ & & $12.4 \mathrm{mg} / \mathrm{dL}$ & $346 \mathrm{pg} / \mathrm{mL}$ & ND & $\begin{array}{l}3.0 \mathrm{~cm} \\
(4.2 \mathrm{~g})\end{array}$ & $P$ & Single & LI \\
\hline $\begin{array}{l}\text { Kodoma et al. } \\
\text { (12) }\end{array}$ & 2007 & $18 / \mathrm{F}$ & NF1 & $11.6 \mathrm{mg} / \mathrm{dL}$ & $356 \mathrm{pg} / \mathrm{mL}$ & $\begin{array}{l}\text { USG (+)/ } \\
\operatorname{TITC}(+)\end{array}$ & $\begin{array}{l}5.0 \mathrm{~cm} \\
(21.7 \mathrm{~g})\end{array}$ & $P$ & Single & RS \\
\hline Liang et al. (13) & 2010 & $59 / F$ & & $11.8 \mathrm{mg} / \mathrm{dL}$ & $265 \mathrm{pg} / \mathrm{mL}$ & $\begin{array}{l}\text { USG (-)/ } \\
\text { MIBI (+) }\end{array}$ & $\begin{array}{l}4.5 \mathrm{~cm} \\
13.3 \mathrm{~g}\end{array}$ & $P$ & Single & RS \\
\hline Bai et al. (14) & 2012 & $81 / \mathrm{M}$ & & NA & $22.2 \mathrm{pmol} / \mathrm{L}$ & $\begin{array}{l}\text { USG (-)/ } \\
\text { MIBI (+) }\end{array}$ & $\begin{array}{l}4.0 \mathrm{~cm} \\
(6.91 \mathrm{~g})\end{array}$ & $P$ & Single & RS \\
\hline Bai et al. (14) & 2012 & $55 / \mathrm{M}$ & & NA & $15.9 \mathrm{pmol} / \mathrm{L}$ & $\begin{array}{l}\text { USG (-)/ } \\
\text { MIBI (-) }\end{array}$ & $\begin{array}{l}1.4 \mathrm{~cm} \\
0.27 \mathrm{~g}\end{array}$ & $\begin{array}{c}\text { P+BTT } \\
\text { (Papillery ca) }\end{array}$ & Single & LS \\
\hline $\begin{array}{l}\text { Papanicolau- } \\
\text { Sengos et al. (15) }\end{array}$ & 2013 & $64 / \mathrm{M}$ & & NA & NA & NA & $4.7 \mathrm{~cm}$ & $P$ & Single & LI \\
\hline $\begin{array}{l}\text { Piggott et al. } \\
\text { (16) }\end{array}$ & 2013 & $74 / F$ & & $3.13 \mathrm{mmol} / \mathrm{L}$ & $488.9 \mathrm{ng} / \mathrm{L}$ & $\begin{array}{l}\text { USG (+)/ } \\
\text { MIBI (+) }\end{array}$ & $\begin{array}{c}5.5 \mathrm{~cm} \\
(13 \mathrm{~g})\end{array}$ & $P$ & Single & LI \\
\hline Ezzat et al. (17) & 2013 & $73 / \mathrm{M}$ & & $3.24 \mathrm{mmol} / \mathrm{L}$ & $30.8 \mathrm{pmol} / \mathrm{L}$ & $\begin{array}{l}\text { USG (+)/ } \\
\text { MIBI (+) }\end{array}$ & $\begin{array}{c}3.7 \mathrm{~cm} \\
(8 \mathrm{~g})\end{array}$ & $P$ & Single & LI \\
\hline Ezzat et al. (17) & 2013 & $74 / F$ & & $2.9 \mathrm{mmol} / \mathrm{L}$ & $11.8 \mathrm{pmol} / \mathrm{L}$ & $\begin{array}{l}\text { USG (+)/ } \\
\text { MIBI (-) }\end{array}$ & $\begin{array}{l}1.6 \mathrm{~cm} \\
(0.9 \mathrm{~g})\end{array}$ & $P$ & Single & LI \\
\hline $\begin{array}{l}\text { Murakami et al. } \\
\text { (18) }\end{array}$ & 2014 & $59 / F$ & & $11.9 \mathrm{mg} / \mathrm{dL}$ & $72.3 \mathrm{pg} / \mathrm{dL}$ & $\begin{array}{l}\text { USG (+)/ } \\
\operatorname{MIBI}(-) / \\
C T(+)\end{array}$ & $\begin{array}{l}0.8 \mathrm{~cm} \\
(0.5 \mathrm{~g})\end{array}$ & $P$ & Single & LI \\
\hline Chou et al (19) & 2014 & $81 / F$ & Pancreatitis & $12 \mathrm{mg} / \mathrm{dL}$ & $450 \mathrm{pg} / \mathrm{mL}$ & $\begin{array}{l}\text { USG (+)/ } \\
\operatorname{MIBI}(+)\end{array}$ & $3.8 \mathrm{~cm}$ & $P$ & Single & NA \\
\hline $\begin{array}{l}\text { Tassone et al. } \\
\text { (20) }\end{array}$ & 2014 & $54 / \mathrm{F}$ & & $12.4 \mathrm{mg} / \mathrm{dL}$ & $130 \mathrm{ng} / \mathrm{L}$ & $\begin{array}{l}\text { USG (+)/ } \\
\text { MIBI (+) }\end{array}$ & $2.8 \mathrm{~cm}$ & $P$ & Single & LI \\
\hline Current Study & 2016 & $47 / M$ & & $16.6 \mathrm{mg} / \mathrm{dL}$ & $744 \mathrm{pg} / \mathrm{mL}$ & $\begin{array}{l}\text { USG (+)/ } \\
\operatorname{MIBI}(-)\end{array}$ & $\begin{array}{l}2.5 \mathrm{~cm} \\
(1.9 \mathrm{~g}) / \\
1.6 \mathrm{~cm} \\
(0.9 \mathrm{~g})\end{array}$ & $P$ & Double & Rinf/Linf \\
\hline
\end{tabular}

PTH: parathyroid hormone; MIBI: technetium-99 m sestamibi scintigraphy; NA: not available; Scinti: scintigraphy; TITc: tallium technetium subtraction scintigraphy; USG: ultrasonography; BTT: bilateral total thyroidectomy; LI: left inferior; LS: left superior; Rl: right inferior; RS: right superior; P: parathyroidectomy

localization than scintigraphy, which is consistent with the observation of USG being more effective in showing adenoma localization than scintigraphy in patients with WCCA in the current patient population.
Classically, in WCCH, there is firstly upper parathyroid gland involvement and hypertrophy in the inferior glands emerges later (9). However, in studies related to parathyroid adenoma localization, it has been reported that majority of cases originate 
in the inferior glands (30). Of the patients for whom complete data were available, it was observed that WCCA behaved like adenoma rather than WCCH with respect to localization. While inferior parathyroidal tissues were involved in 11 patients, upper pole localization was seen in 5 patients and intrathyroidal localization was seen in 1 patient.

\section{CONCLUSION}

WCCA causing hyperparathyroidism is an extremely rare event. Although localization is determined less effectively compared with other types of adenoma, USG seems to be relatively effective. Moderate level hypercalcemia has been previously reported in literature, but it should be kept in mind that as reported for the first time in the current case, there could be a cause of hypercalcemia at a level requiring treatment.

From the behavior and localization, although it is thought to be adenoma rather than $\mathrm{WCCH}$, as the number of patients increases in the future, clearer information will be able to be obtained.

Ethics Committee Approval: Authors declared that the research was conducted according to the principles of the World Medical Association Declaration of Helsinki "Ethical Principles for Medical Research Involving Human Subjects" (amended in October 2013).

Informed Consent: Written informed consent was obtained from patients who participated in this study.

Peer-review: Externally peer-reviewed.

Author Contributions: Concept - F.M.Y., E.B.; Design - F.E., A.I., M.K. Supervision - F.M.Y., E.B., F.E.; Resource - E.B., F.E., F.M.Y.; Materials - A.I. M.K., F.E.; Data Collection and/or Processing - F.M.Y., A.I., M.K.; Analysis and/or Interpretation - F.M.Y., E.B., F.E.; Literature Search - A.I., M.K.; Writing Manuscript - F.M.Y., A.I., M.K.K.; Critical Reviews - E.B., F.E.

Conflict of Interest: No conflict of interest was declared by the authors.

Financial Disclosure: The authors declared that this study has received no financial support.

\section{REFERENCES}

1. Piggott RP, Waters PS, Ashraf J, Colesky F, Kerin MJ. Water-clear cell adenoma: A rare form of hyperparathyroidism. Int J Surg Case Rep 2013, 4: 911-913. [CrossRef]

2. Kuhel WI, Gonzales D, Hoda SA, Pan L, Chiu A, Giri D, et al. Synchronous water-clear cell double parathyroid adenomas a hitherto uncharacterized entity? Arch Pathol Lab Med 2001; 125: 256-259.

3. Albright F, Bloomberg E, Castleman B, Churchill ED. Hyperparathyroidism dueto diffuse hyperplasia of all parathyroid glands rather than adenoma of one: clinical studies on three such cases. Archives of Internal Medicine 1934; 54: 315-329. [CrossRef]

4. Kovacs K, Horvath E, Ozawa Y, Yamada S, Matushita H. Large clear cell adenoma of the parathyroid in a patient with MEN-1 syndrome: ultrastructural study of the tumour exhibiting unusual RER formations. Acta Biol Hung 1994; 45: 275-284.

5. Roth SI. Water-clear cell'adenoma'. A new entity in the pathology of primary hyperparathyroidism. Arch Pathol Lab Med 1995; 119: 11: 996-997.

6. Grenko RT, Anderson KM, Kauffman G, Abt AB. Water-clear cell adenoma of the parathyroid. A case report with immunohistochemistry and electron microscopy. Arch Pathol Lab Med 1995; 119: 1072-1074.

7. Bégueret $H$, Belleannée G, Dubrez J, Trouette H, Parrens M, Velly $\mathrm{JF}$, et al. Clear cell adenoma of the parathyroid gland: a rare and misleading lesion. Ann Pathol 1999; 19: 316-319.
8. Dundar E, Grenko RT, Akalin A, Karahuseyinoglu E, Bildirici K. Intrathyroidal water-clear cell parathyroid adenoma: a case report. Hum Pathol 2001; 32: 889-892. [CrossRef]

9. Kuhel WI, Gonzales D, Hoda SA, Pan L, Chiu A, Giri D, et al. Synchronous water-clear cell double parathyroid adenomas a hitherto uncharacterized entity? Arch Pathol Lab Med 2001; 125: 256-259.

10. Kanda K, Okada Y, Tanikawa T, Morita E, Tsurudome Y, Konishi T, et al. A rare case of primary hyperparathyroidism with clear cell adenoma. Endocr J 2004; 51: 207-212. [CrossRef]

11. Prasad KK, Agarwal G, Krishnani N. Water-clear cell adenoma of the parathyroid gland: a rare entity. Indian J Pathol Microbiol 2004; 47: 39-40.

12. Kodama $\mathrm{H}$, lihara $\mathrm{M}, \mathrm{Okamoto} \mathrm{T}, \mathrm{Obara} \mathrm{T}$. Water-clear cell parathyroid adenoma causing primary hyperparathyroidism in a patient with neurofibromatosis type 1: report of a case. Surg Today 2007; 37: 884-887. [CrossRef]

13. Liang Y, Mojica W, Chen F. Water-Clear Cell Adenoma of Parathyroid Gland: A Case Report and Literature Review. North Am J of Med and Science 2010; 3: 194-198. [CrossRef]

14. Bai S, LiVolsi VA, Fraker DL, Bing Z. Water-clear parathyroid adenoma: report of two cases and literature review. EndocrPathol 2012; 23: 196-200. [CrossRef]

15. Papanicolau-Sengos A, Brumund K, Lin G, Hasteh F. Cytologic findings of a clear cell parathyroid lesion. Diagn Cytopathol 2013; 41:725-728. [CrossRef]

16. Piggott RP, Waters PS, Ashraf J, Colesky F, Kerin MJ. Water-clear cell adenoma: A rare form of hyperparathyroidism. Int J Surg Case Rep 2013; 4: 911-913. [CrossRef]

17. Ezzat T, Maclean GM, Parameswaran R, Phillips B, Komar V, Mihai R, et al. Primary hyperparathyroidism with water clear cell content: the impact of histological diagnosis on clinical management and outcome. Ann R Coll Surg Engl 2013; 95: 60-62. [CrossRef]

18. Murakami K, Watanabe M, Nakashima N, Fujimori K, Ishida K, Ohuchi $\mathrm{N}$, et al. Water-clear cell adenoma associated with primary hyperparathyroidism: report of a case. Surg Today 2014; 44: 773-777. [CrossRef]

19. Chou YH, Jhuang JY, Hsieh MS. Water-clear cell parathyroid adenoma in a patient with acute pancreatitis. J Formos Med Assoc 2014; 113: 11: 872-873. [CrossRef]

20. Tassone P,Kaplan S,Kenyon L, Rosen D, Pribitkin E. Water Clear Cell Parathyroid Adenoma: Case Report and Literature Review. Thyroid Disorders Ther 2014: 3: 160.

21. Hanes FM. Hyperparathyroidism due to parathyroid adenoma with death from parathormone intoxication. Am J Med Sci 1939; 197: 85-90. [CrossRef]

22. Harness JK, Ramsburg SR, Nishiyama RH, Thompson NW. Multiple adenomas of the parathyroid: do they exist? Arch Surg 1979; 114: 468-474. [CrossRef]

23. Haynes Jl. Parathyroid morphology of the brush-tail possum, Trichosurus vulpecula, Anat Rec 1995, 241: 401-410. [CrossRef]

24. Wild $\mathrm{P}$, SetogutiT. Mammalian parathyroids: morphological and functional implications, Microsc Res Tech 1995, 32: 120-128. [CrossRef]

25. Reinhard Ziegler. Hypercalcemic crisis. J Soc Nephrol 2001; 12: 3-9.

26. Gurrado A, Piccinni G, Lissidini G, Di Fronzo P, Vittore F, Testini $M$. Hypercalcaemic crisis due to primary hyperparathyroidism - a systematic literature review and case report. Endokrynol Pol 2012; 63: 6: 494-502.

27. Marcocci C, Cetani F. Primary hyperparathyroidism. N Engl J Med 2011; 365: 2389-2397. [CrossRef]

28. Marienhagen K, Due J, Hanssen TA, Svartberg J. Surviving extreme hypercalcaemia--a case report and review of the literature. J Intern Med 2005; 258: 1: 86-89. [CrossRef]

29. Khorasani N, Mohammadi A. Effective factors on the sensitivity of preoperative sestamibi scanning for primary hyperparathyroidism. Int J Clin Exp Med 2014; 7: 2639-2644.

30. Hoang JK, Sung WK, Bahl M, Phillips CD. How to perform parathyroid 4D CT: tips and traps for technique and interpretation. Radiology 2014; 270: 15-24. [CrossRef] 